\title{
PENGARUH MOTIVASI, KOMPENSASI DAN IKLIM ORGANISASI TERHADAP KEPUASAN KERJA GURU SMK KABUPATEN BIREUEN
}

\author{
Fadhli $^{\left.1^{*}\right)}$ dan Marwan ${ }^{2)}$ \\ 1, Magister Manajemen Fakultas Ekonomi Bisnis UNIKI \\ 2 Dosen Universitas Almuslim Bireuen - Aceh \\ *email: fadhlimdaud68@gmail.com
}

DOI:

ABSTRACT

https://doi.org/10.55178/idm.v1i2.199

Article history

Received:

September 14, 2020

Revised:

September 20, 2020

Accepted:

September 30, 2020

Page:

$62-75$

Keywords:

Motivation

Compensation,

Organizational Climate,

Job Satisfaction
The purpose of this study was to determine a) The effect of teacher's motivation to affect Job Satisfaction in Teachers in Vocational Schools in Bireuen Regency, b). Influence of Compensation on Job Satisfaction in Teachers in Vocational Schools in Bireuen District, c). The climate of the School organization on Job Satisfaction in Teachers in Vocational Schools in Bireuen District, and d). The effect of Work Motivation, Compensation, and Organizational Climate simultaneously on Job Satisfaction in Teachers in Vocational Schools in Bireuen District. This type of explanatory research that explains the causal relationship and influence between variables through hypothesis testing, so that the influence of independent variables is known namely work motivation (X1), Compensation (X2), Organizational Climate (X3) on dependent variables, namely Teacher Job Satisfaction (Y). The research method is quantitative, with a path analysis approach to the research sample of 184 teachers in vocational schools in Bireuen Regency in 2020. The results of the analysis, indicate the influence of teacher motivation on vocational teacher satisfaction by $7.34 \%$. The influence of the Compensation factor on Vocational Teacher Satisfaction is $13.33 \%$. And there is the influence of the climate of school organizations on vocational teacher satisfaction by $55.00 \%$. Descriptive analysis results, found that, a). the level of teacher motivation is good, reaching $82.55 \%$. b). Expected Compensation Level has reached $82.36 \%$, and c). School climate support for teacher satisfaction reaches $87.56 \%$. As well as d). The level of teacher satisfaction reached the good category, which was $.83 .57 \%$, than expected. Based on the coefficient of determination statistics explained that the contribution of work motivation, organizational compensation and climate factors to the satisfaction of state Vocational School teachers in Bireuen was $76.1 \%$.

\section{Pendahuluan (Introduction)}

Guru adalah komponen terpenting dalam menciptakan sumber daya manusia yang berkualitas sesuai dengan cita-cita luhur bangsa yang tertuang dalam tujuan pendidikan nasional. Oleh sebab itu, dibutuhkan sikap profesional guru dalam proses pembelajaran. Tanpa sikap professional, suatu institusi seperti lembaga pendidikan tidak mungkin memperoleh hasil yang maksimal. Guru sebagai tenaga pendidik adalah tokoh yang paling banyak bergaul dan berinteraksi dengan para peserta didik dibandingkan dengan personel lainnya di sekolah. Tugas guru merencanakan serta melaksanakan proses pembelajaran, menilai hasil pembelajaran, melakukan bimbingan dan pelatihan, melakukan penelitian dan pengkajian, dan membuka komunikasi dengan masyarakat. Dari pengertian tersebut, maka dapat disimpulkan bahwa guru merupakan kunci keberhasilan sebuah lembaga pendidikan. Baik atau buruknya perilaku atau cara mengajar guru akan sangat mempengaruhi citra lembaga pendidikan.

Salah satu tujuan penting pada manajemen sumber daya manusia dalam organisasi adalah terciptanya kepuasan kerja para pegawai, demikian pula dalam manajemen sekolah, perlu diperhatikan kepuasan kerja guru, sehingga pada gilirannya dapat dicapai tujuan yang dicanangkan pada sekolah tersebut. Agar guru dapat bekerja secara optimal dan produktif, maka kepuasan guru merupakan komponen yang tidak boleh diabaikan karena akan berpengaruh pada produktifitasnya (Sergiovani, 2006: 24). 
Kepuasan kerja pada dasarnya merupakan salah satu aspek psikologis yang mencerminkan perasaan seseorang terhadap pekerjaannya, pekerja atau guru merasa puas dengan adanya kesesuaian antara kemampuan, keterampilan dan harapannya dengan pekerjaan yang dihadapinya. Dan kepuasan kerja merupakan hal yang bersifat individual karena setiap individu memiliki tingkat kepuasan yang berbedabeda sesuai dengan nilai-nilai yang berlaku dalam diri setiap individu. Semakin banyak aspek dalam pekerjaan yang sesuai dengan keinginan individu, maka semakin tinggi tingkat kepuasan yang dirasakan. Hal ini sependapat dengan Handoko (2001:93) bahwa "karyawan bekerja dengan produktif atau tidak bergantung pada motivasi, kepuasan kerja, tingkat stress, kondisi fisik pekerjaan, sistem kompensasi, desain pekerjaan, aspek-aspek ekonomis, teknis dan perilaku lainnya."

Kepuasan sebenarnya merupakan keadaan yang sifatnya subyektif, yang merupakan hasil suatu perbandingan mengenai apa yang diterima pegawai atau guru dari pekerjaannya dibandingkan dengan yang diharapkan, diinginkan, dan dipikirkannya sebagai hal yang pantas atau berhak atasnya. Sementara setiap pegawai atau guru secara subyektif menentukan bagaimana pekerjaan itu memuaskan bagi dirinya.

Kepuasan kerja adalah sikap emosional yang menyenangkan dan mencintai pekerjaannya. Sikap ini dicerminkan oleh moral kerja, kedisiplinan dan prestasi kerja. Kepuasan kerja dinikmati dalam pekerjaan, luar pekerjaan, dan kombinasi dalam dan luar pekerjaan. Jadi kepuasan kerja mengandung arti yang sangat penting, baik dari sisi guru maupun sekolah atau lembaga pendidikan, serta bagi masyarakat secara umum. Oleh karena itu menciptakan keadaan yang bernilai positif dalam lingkungan kerja suatu organisasi mutlak merupakan kewajiban dari setiap jajaran pimpinan yang bersangkutan.

Kepuasan kerja merupakan impian dan harapan setiap guru, tetapi banyak faktor yang menyebabkan puas atau tidak puasnya seorang guru dalam melaksanakan tugas sebagai pengajar dan pendidik. Menurut Halawa (2002:12) faktor-faktor tersebut adalah lingkungan kerja, disiplin kerja, gaji/honor, hubungan guru dengan guru, hubungan guru dengan kepala sekolah, hubungan guru dengan siswa, motivasi, pengaruh kepemimpinan kepala sekolah, sikap guru, pengetahuan tentang komunikasi. Semua faktor tersebut langsung atau tidak langsung berpengaruh terhadap kepuasan kerja.

Menurut Kreitner dan Kinicki (2001:271) kepuasan kerja adalah "suatu efektifitas atau respons emosional terhadap berbagai aspek pekerjaan". Dengan merasa puasnya karyawan, hal ini akan secara otomatis berdampak pada efektifnya suatu pekerjaan. Beberapa ahli manajemen memberikan gambaran nyata tentang faktor-faktor yang mempengaruhi Kepuasan kerja, termasuk kepuasan kerja guru, yakni kompensasi (Robbins, 2012:60), leadership, jaringan kerja, budaya organisasi (Luthan, 1998:145.), motivasi (Eklund, 2008:18), kepemimpinan (Hasibuan, 2003:203), komunikasi organisasi (Kreitner dan kinicki, 2001:271).

Menurut Hasibuan (2003:203), kepuasan kerja dipengaruhi oleh banyak faktor antara lain : 1) Balas jasa yang adil dan layak, 2) Penempatan yang tepat dan sesuai dengan keahlian, 3) Suasana dan lingkungan pekerjaan, 4) Berat ringannya pekerjaan, 5) Peralatan yang menunjang, dan 6) Sikap pimpinan dalam kepemimpinannya. Juga Robbins (2002:36), menyatakan kepuasan kerja karyawan dipengaruhi oleh factor-faktor, seperti: pekerjaan yang menantang, penghargaan, kondisi lingkungan kerja dan hubungan interpersonal.

Kepuasan kerja sesorang dalam bekerja, tidak terlepas dari tingkat motivasinya dalam bekerja. Karena motivasi adalah serangkaian sikap dan nilai yang mempengaruhi individu untuk mencapai hal yang spesifik sesuai dengan tujuan individu (Rivai (2009: 837). Seorang karyawan yang termotivasi akan bersifat energik dan bersemangat dalam mengerjakan tugas-tugas yang diberikan oleh perusahaan, dan sebaliknya seorang karyawan dengan motivasi yang rendah akan sering menampilkan rasa tidak nyaman dan tidak senang terhadap pekerjaannya yang mengakibatkan kinerja mereka menjadi buruk dan tujuan perusahaan tidak akan tercapai (Murty dan Hundiwinarsih, 2012).

Teori motivasi terbaik yang diketahui adalah teori hierarki kebutuhan dari Abraham Maslow, yang menyatakan bahwa di dalam diri setiap manusia terdapat hierarki lima kebutuhan yaitu kebutuhan fisiologis, kebutuhan rasa aman, sosial, penghargaan, dan aktualisasi diri (Robbins, 2015;128). Ayub dan Rafif (2011) dalam penelitiannya menyatakan bahwa terdapat hubungan yang positif antara motivasi pekerjaan dan kepuasan kerja. Hal senada diungkapkan oleh Saeed et al. (2013) yang menyatakan bahwa motivasi ekstrinsik memiliki hubungan positif dengan kepuasan kerja.

Selain faktor motivasi pegawai, hal eksternal yang berdampak langsung pada kepuasan kerja individu pegawai adalah adanya kompensasi yang adil dan diperoleh secara proporsional dengan beban dan tugas pegawai. Kompensasi adalah semua pendapatan yang berbentuk uang, barang langsung, atau tidak langsung yang diterima karyawan sebagai imbalan atas jasa yang diberikan kepada perusahaan (Hasibuan, 2009: 
118). Dalam hal ini adalah factor kompensasi menjadi sesuatu yang berarti dalam kepuasan kerja pegawai atau karyawan. Sebagaimana dinyatakan Dessler (2007:46) bahwa kompensasi merujuk pada semua bentuk bayaran atau hadiah bagi karyawan dan berasal dari pekerjaan mereka. Sedangkan menurut Handoko (2001:156), menyatakan cara meningkatkan prestasi, motivasi kerja dan kepuasan kerja adalah dengan memberikan kompensasi.

Permasalahan yang dihadapi sekolah terhadap tingkat kepuasan kerja guru diantaranya: 1) Kompensasi yang diperoleh guru tidak cukup untuk standar hidup layak minimal sesuai dengan peraturan daerah yang berlaku, 2) Pembayaran kompensasi tidak tepat waktu 3) Beban kerja tidak sesuai dengan kompensasi yang diperoleh 4) Tidak ada kepastian pengangkatan menjadi tenaga guru PNS 5) Adanya sub budaya yang mendiskriminasikan antara guru PNS dengan guru non PNS di lingkungan sekolah, 6) kecenderungan untuk mengundurkan diri jika ada pekerjaan yang lebih berarti di kalangan para guru non PNS 7) Tingkat absensi dikalangan guru mempengaruhi mekanisme sistem pembelajaran. 8) Guru non PNS tidak merasa memiliki keterikatan dengan lembaga pendidikan (Zain, 2016:13).

Selain hal tersebut, kepuasan juga terkait dengan iklim organisasi sekolah, terutama yang berkaitan dengan sarana prasarana sekolah, seperti kebersihan sekolah, kenyamanan ruang kelas serta keindahan halaman sekolah, masih sangat memprihatinkan. Iklim organisasi adalah lingkungan dimana para pegawai organisasi melakukan pekerjaan mereka. Iklim organisasi sebagai sistem yang dinamis dipengaruhi oleh hampir semua hal yang terjadi dalam suatu organisasi. Jadi iklim organisasi merupakan konsep sistem yang mencerminkan keseluruhan gaya hidup organisasi (Zain, 2016:16). Karena iklim organisasi mencerminkan gaya hidup, maka secara otomatis iklim organisasi akan mempengaruhi keseluruhan kegiatan organisasi termasuk perilaku anggotanya. Hoy dan Miskel (2001:198) mengemukakan bahwa, "School climate is a broad term that refers to teachers perspection of general work environment of school, the formal organization, informal organization, personalities of participant, and organizational leadership influence it. The definition of organization climate as a set of internal characteristic is similar in some respect to early description of personality".

Jadi Iklim organisasi sekolah akan memberi pengaruh pada perilaku guru dalam melaksanakan tugasnya di sekolah, terutama rasa kepuasan bekerja, Karena iklim di sekolah sangat mendukungnya. Pentingnya memperhatikan iklim yang ada pada organisasi sekolah merupakan suatu gambaran bahwa pencapaian tujuan organisasi sekolah juga akan dapat dicapai, seperti mutu sekolah, meningkatkan hasil belajar siswa, dan inovasi berprestasi pada jiwa guru, baik secara individu ataupun kelompok guru. Hasil temuan penelitian dari Zain (2016), bahwa kepuasan guru dalam bekerja tidak terlepas dari faktor iklim organisasi sekolah.

Dari uraian tentang konsep teoritis dan empiris diatas, dan kenyataan yang ada dalam lingkungan SMK Kabupaten Bireuen, penulis tertarik untuk dapat meneliti bagaimana Hubungan Antara Motivasi, Kompensasi dan Iklim Organisasi dengan Kepuasan Kerja Guru SMK Kabupaten Bireuen.

\section{Tinjauan Literatur (Literature Review)}

\section{a. Pengaruh Motivasi terhadap Kepuasan Kerja}

Motivasi kerja adalah dorongan atau semangat yang timbul dari diri seseorang atau pegawai untuk melakukan sesuatu atau bekerja, karena adanya rangsangan dari luar baik itu dari atasan dan lingkungan kerja serta adanya dasar untuk memnuhi kebutuhan dan rasa puas seta memenuhi tanggung jawab atas tugas-tugas yang diberikan dan dilakukan dalam organisasi.

Motivasi adalah kesediaan individu untuk mengeluarkan upaya yang tinggi untuk mencapai tujuan organisasi (Robbins, 2001). Ada tiga elemen kunci dalam motivasi yaitu upaya, tujuan organisasi dan kebutuhan. Upaya merupakan ukuran intensitas. Bila seseorang termotivasi maka ia akan berupaya sekuat tenaga untuk mencapai tujuan, namun belum tentu upaya yang tinggi akan menghasilkan kinerja yang tinggi. Oleh karena itu, diperlukan intensitas dan kualitas dari upaya tersebut serta difokuskan pada tujuan organisasi.

Dalam kehidupan berorganisasi, pemberian dorongan sebagai bentuk motivasi kerja pada bawahan penting dilakukan untuk meningkatkan kinerja pegawai, motivasi merupakan faktor yang kehadirannya dapat menimbulkan kepuasan kerja, dan meningkatkan kinerja pegawai (Umar, 1999). Selanjutnya Masrukhin dan Waridin (2006) mengemukakan bahwa motivasi merupakan faktor psikologi yang menunjukkan minat individu terhadap pekerjaan, rasa puas, dan ikut bertanggung jawab terhadap aktivitas atau pekerjaan yang dilakukan. 
Adapun tujuan pemberian motivasi. antara lain: 1) Mendorong gairah dan semangat kerja bawahan, 2) Meningkatkan moral dan kepuasan kerja karyawan; 3) Meningkatkan produktivitas kerja karyawan; 4) Mempertahankan loyalitas dan kestabilan karyawan perusahaan; 5) Meningkatkan disiplin dan menurunkan tingkatan abseni karyawan;6) Menciptakan suasana dan hubungan kerja yang baik; 7) Meningkatkan kreativitas dan partisipasi karyawan; 8) Meningkatkan kesejahteraan karyawan; 9) Mempertinggi rasa tanggung jawab karyawan terhadap tugas-tugasnya (Hasibuan, 2014:35).

Jadi antara motivasi dan kepuasan kerja terdapat hubungan yang positif dan signifikan. Karena kepuasan dengan pengawasan/supervisi juga mempunyai korelasi signifikan dengan motivasi, atasan/manajer disarankan mempertimbangkan bagaimana perilaku mereka mempengaruhi kepuasan pekerja sehingga mereka secara potensial dapat meningkatkan motivasi pekerja melalui berbagai usaha untuk meningkatkan kepuasan kerja.

Motivasi terhadap kepuasan kerja adalah motivasi yang ada pada diri seseorang merupakan kekuatan pendorong yang mewujudkan suatu perilaku guna mencapai tujuan kepuasan dirinya (Handoko, 2008:194). Rivai (2004:456) mengatakan bahwa hubungan motivasi terhadap kepuasan kerja adalah apabila individu termotivasi, mereka akan membuat pilihan yang positif untuk melakukan sesuatu, karena dapat memuaskan keinginan mereka.

\section{b. Pengaruh Kompensasi terhadap Kepuasan Kerja}

Kompensasi adalah semua pendapatan yang berbentuk uang, barang langsung atau tidak langsung yang diterima karyawan sebagai imbalan atas jasa yang diberikan kepada perusahaan (Hasibuan, 2003:19). Kompensasi disebut juga dengan penghargaan atau ganjaran dan dapat didefinisikan sebagai setiap bentuk penghargaan yang diberikan kepada karyawan sebagai balas jasa atas kontribusi yang mereka berikan kepada organisasi (Panggabean, 2002:75).

Dalam mengelola sebuah sekolah, guru merupakan aset yang sangat penting karena tanpa adanya guru, sekolah akan sulit untuk mencapai tujuan pendidikan. Sebaik apa pun kurikulum yang diterapkan dalam dunia pendidikan, guru tetap berperan sangat besar untuk mencapai tujuan dari kurikulum tersebut. Peran guru sangat penting dan tidak dapat dibedakan antara guru yang telah bersertifikat dengan guru yang belum bersertifikat, keduanya tetap harus bekerja secara profesional. UU no 14 tahun 2005 tentang guru dan dosen Pasal 1 ayat 1 mendefinisikan bahwa guru adalah pendidik profesional dengan tugas utama mendidik, mengajar membimbing, mengarahkan, melatih, menilai dan mengevaluasi peserta didik pada pendidikan anak usia dini, jalur pendidikan formal, pendidikan dasar dan pendidikan menengah.

Banyak faktor yang mempengaruhi keberhasilan di sekolah dalam mencapai tujuan pendidikan. Salah satunya adalah guru, karena berkaitan langsung dengan kegiatan pembelajaran di sekolah. Dalam hal ini guru diharapkan dapat memberikan hasil yang maksimal sehingga tujuan pendidikan disekolah dapat tercapai. Oleh karena itu untuk mendukung agar tujuan pendidikan di sekolah berhasil secara maksimal, maka perlu diperhatikan mengenai kepuasan kerja guru.

Kepuasan kerja merupakan salah satu komponen dari kepuasan hidup, sehingga menjadi hal yang sangat penting untuk diperhatikan dalam pengembangan karir guru. Bila guru tidak mendapatkan kepuasan dari pekerjaannya, maka motivasi mereka dapat menurun, absensi dan keterlambatan meningkat dan menjadi semakin sulit untuk bekerjasama atau untuk mengadakan suatu perubahan. Hal ini menunjukkan bahwa kepuasan kerja guru ikut menjadi penentu terhadap keberhasilan sekolah dalam mewujudkan tujuan pendidikan. Kepuasan kerja sangat berpengaruh bagi kelangsungan kegiatan organisasi di sekolah. Karena kepuasan kerja guru dapat menimbulkan perasaan yang menyenangkan atau tidak menyenangkan dalam bekerja sehingga dapat mempengaruhi kinerja guru.

Permasalahan kepuasan kerja guru tidak terlepas dari apa yang diterima oleh guru itu sendiri. Faktor kompensasi menjadi hal yang bisa mempengaruhi kepuasan kerja guru. Jika hak dari guru dapat terpenuhi kepuasan guru juga akan meningkat, yang menyebabkan tujuan pendidikan di sekolah dapat tercapai. Menurut Zainal dkk (2016: 541) kompensasi adalah sesuatu yang diterima guru sebagai pengganti kontribusinya pada sekolah. Menurut Hasibuan (2003:118) kompensasi adalah semua pendapatan yang berbentuk uang, barang langsung atau tidak langsung yang diterima karyawan sebagai imbalan jasa atas jasa yang diberikan kepada perusahaan. Kompensasi yang diberikan kepada guru sangat berpengaruh pada tingkat kepuasan kerja, motivasi kerja dan hasil kerja (Mangkunegara, 2015: 84).

Jika di sekolah tidak mampu memberikan kompensasi yang sesuai dan tepat waktu akan terjadi sebaliknya yaitu kepuasan bekerja guru akan rendah dan dampak yang paling jelas yakni sekolah tersebut akan kalah bersaing dengan sekolah sejenisnya. 


\section{c. Pengaruh Iklim Organisasi terhadap Kepuasan Kerja}

Iklim organisasi adalah sebagai koleksi dan pola lingkungan yang menentukan munculnya motivasi serta berfokus pada persepsi-persepsi yang masuk akal atau dapat dinilai, sehingga mempunyai pengaruh langsung terhadap kinerja anggota organisasi. Menurut Davis dan Newstrom (2000:34): Iklim organisasi adalah sebuah konsep yang menggambarkan suasana internal lingkungan organisasi yang dirasakan anggotanya selama mereka beraktivitas dalam rangka tercapainya tujuan organisasi.

Iklim dan lingkungan sekolah mempunyai pengaruh yang cukup besar terhadap kepuasan kerja guru dalam pembelajaran. Sebab iklim yang kondusif memberi perasaan nyaman dan bebas baik bagi para guru maupun para siswa belajar ( Pidarta,1997:67). Kepuasan kerja guru adalah perasaan yang menyokong atau tidak menyokong dalam diri pegawai yang berhubungan dengan pekerjaan maupun kondisi dirinya.

Pemahaman iklim sekolah sebagai kepribadian suatu sekolah merujuk pada beberapa pendapat berikut. Halpin dan Croft (dalam Tubbs dan Garner, 2008:17) menjelaskan iklim sekolah sebagai sesuatu yang intangible tetapi penting untuk sebuah organisasi dan dianalogikan dengan kepribadian seorang individu. Hoy dan Miskel (dalam Pretorius dan Villiers, 2009:33) menjelaskan: "iklim sekolah merujuk kepada hati dan jiwa dari sebuah sekolah, psikologis dan atribut institusi yang menjadikan sekolah memiliki kepribadian, yang relatif bertahan dan dialami oleh seluruh anggota, yang menjelaskan persepsi kolektif dari perilaku rutin, dan akan mempengaruhi sikap dan perilaku di sekolah". Sorenson dan Goldsmith (2008:30) memandang iklim sekolah sebagai kepribadian kolektif dari sekolah. Oleh karena itu inti dari iklim sekolah adalah bagaimana kita memperlakukan satu dengan lainnya. Dan Cohen et.al. (dalam Pinkus, 2009:14) menjelaskan iklim sekolah sebagai kualitas dan karakter dari kehidupan sekolah, berdasarkan pola perilaku siswa, orang tua dan pengalaman personil sekolah tentang kehidupan sekolah yang mencerminkan normanorma, tujuan, nilai, hubungan interpersonal, praktek belajar dan mengajar, serta struktur organisasi.

Kepuasan kerja merupakan impian dan harapan setiap guru, akan tetapi banyak faktoryang menyebabkan puas atau tidak puasnya seorang guru dalam melaksanakan tugassebagai pengajar dan pendidik. Menurut Halawa (2002:12) Faktor-faktor tersebut adalah lingkungan kerja, disiplin kerja,gaji/honor, hubungan guru dengan guru, hubungan guru dengan kepala sekolah, hubungan guru dengan siswa, motivasi,pengaruh kepemimpinan kepala sekolah, sikap guru, pengetahuan tentang komunikasi. Semua faktor tersebut langsung atau tidak langsung berpengaruh terhadap kepuasan kerja.

\section{Metodologi Penelitian (Methodology)}

\section{a. Metode Penelitian dan Unit Analisis}

Dalam penelitian ini, penulis menggunakan jenis penelitian kuantitatif dengan metode eksplanatori, yang menjelaskan hubungan kausal dan pengaruh antar variabel melalui pengujian hipotesis, yakni menjelaskan pengaruh variabel Motivasi kerja, Kompensasi, dan Iklim Organisasi terhadap Kepuasan Kerja Guru.

Penelitian ini dilaksanakan pada Sekolah Menengah Kejuruan (SMK se- Kabupaten Bireuen, dengan objek penelitiannya adalah guru-guru PNS dan Non-PNS, pada Januari 2020. Populasi dalam penelitian ini adalah seluruh guru PNS pada SMK di Kabupaten Bireuen, tahun ajaran 2019-2020, yang berjumlah 341 orang. Dengan sebarannya pada 12 SMK di Kabupaten Bireuen. Dari sejumlah guru tersebut, diambil sampel, yakni 184 guru yang dipilih secara proporsional dari setiap sekolah, dimana ukuran sampel di tetapkan dengan perhitungan menggunakan rumus Slovin untuk tingkat kesalahan 5\%.

\section{b. Operasional Variabel Penelitian}

Tabel 1. Operasional variabel Penelitian

\begin{tabular}{|c|c|c|c|}
\hline Variabel & Dimensi & Indikator & Skala Pengukuran \\
\hline $\begin{array}{l}\text { Motivasi kerja } \\
\left(\mathrm{X}_{1}\right)\end{array}$ & 1. Motivasi internal & $\begin{array}{l}\text { 1. Tanggung jawab terhadap pekerjaan, } \\
\text { 2. Memiliki minat terhadap pekerjaan, } \\
\text { 3. Kepuasan dalam bekerja, } \\
\text { 4. Adanya kebutuhan yang harus dipenuhi, dan } \\
\text { 5. Semangat dalam bekerja } \\
\text { 1. Memperoleh pujian atau perhatian dari orang } \\
\text { lain, } \\
\text { 2. Ingin mendapatkan insen-tif/imbalan, } \\
\text { 3. Keinginan untuk men-dapatkan penghargaan } \\
\text { atau prestasi. }\end{array}$ & $\begin{array}{c}\text { Likert-5 } \\
\text { Data Ordinal }\end{array}$ \\
\hline
\end{tabular}




\begin{tabular}{|c|c|c|c|}
\hline & & $\begin{array}{l}\text { 4. Dorongan dari atasan, } \\
\text { 5. Hubungan antar pribadi } \\
\text { 6. Kondisi kerja }\end{array}$ & \\
\hline $\begin{array}{c}\text { Kompensasi } \\
\left(\mathrm{X}_{2}\right)\end{array}$ & $\begin{array}{l}\text { 1.Finansial } \\
\text { 2.Non Finansial }\end{array}$ & $\begin{array}{l}\text { 1.Gaji , 2. Bonus, 3. Insentif } \\
\text { 1.Fasilitas, 2.Lingkungan kerja, 3. Penghargaan }\end{array}$ & $\begin{array}{c}\text { Likert-5 } \\
\text { Data Ordinal }\end{array}$ \\
\hline $\begin{array}{l}\text { Iklim } \\
\text { organisasi } \\
\left(\mathrm{X}_{3}\right)\end{array}$ & $\begin{array}{l}\text { 1.Kondisi Fisik } \\
\text { Lingkungan } \\
\text { organisasi } \\
\text { 2.Hubungan antar } \\
\text { anggota organisasi }\end{array}$ & $\begin{array}{l}\text { 1. Sarana dan } \\
\text { 2. prasarana } \\
\text { 1. Hubungan pertemanan diantara guru / collegial } \\
\text { 2. Kedekatan antara sesama guru atau intimate } \\
\text { 3. Hubungan saling mendukung antar guru atau } \\
\text { supportive. }\end{array}$ & $\begin{array}{c}\text { Likert-5 } \\
\text { Data Ordinal }\end{array}$ \\
\hline $\begin{array}{c}\text { Kepuasan } \\
\text { kerja } \\
\text { (Y) }\end{array}$ & $\begin{array}{ll}\text { 1. } & \text { Kualitas } \\
\text { 2. } & \text { Ketepatan Waktu } \\
\text { 3. } & \text { Inisiatif } \\
\text { 4. } & \text { Komunikasi. }\end{array}$ & $\begin{array}{l}\text { 1. Kemampuan, 2.Ketelitian } \\
\text { 1. Waktu mengajar, 2.Kehadiran, 3.Tata Tertib } \\
\text { 1. Gagasan, 2.Kreatif } \\
\text { 1. Internal, 2.Eksternal }\end{array}$ & $\begin{array}{c}\text { Likert-5 } \\
\text { Data Ordinal }\end{array}$ \\
\hline
\end{tabular}

\section{c. Metode Analisis}

Teknik analisis data dalam peneltian kuantitatif mengunakan pendekatan metode dan alat statistik parametrik. Karena penelitian ini ingin mengetahui jawaban atas hipotesis berdasarkan uji statistik, sehingga penelitian ini menggunakan statistik inferensi. Yang mana statistik inferensi adalah bagian statistik yang mempelajari penafsiran dan penarikan kesimpulan yang berlaku secara umum dari data yang tersedia. Misbahuddin dan Hasan (2013:2). Data penelitian selanjutnya dianalisis secara deskriptif, dan verifikatif yang diikuti dengan menguji persyaratan analisis dan menguji hipotesis penelitian dengan menggunakan analisis model jalur (Path Analysis).

Statistik deskriptif adalah statistik berfungsi mendeskripsikan terhadap objek yang diteliti melalui data sampel atau populasi sebagaimana adanya tanpa melakukan analisis dan membuat kesimpulan berlaku secara umum (Supardi, 2013:20). Analisis data deskriptif dilakukan untuk melihat seberapa besar atau tinggi pencapaian dari variabel penelitian yakni pencapaian Motivasi, Kompensasi, Iklim Organisasi, dan Kepuasan Kerja guru di lingkungan SMK Kabupaten Bireuen.

Sedangkan analisis verifikatif antar variabel, digunakan dengan analisis jalur, sehingga dapat diketahui besarnya pengaruh suatu variabel terhadap variabel lainnya baik pengaruh langsung maupun tidak langsung. Langkah dalam melakukan analisis data dengan menggunakan analisis jalur sesuai dengan modifikasi dari Harun dalam Nirwana (2014:19-28). Besarnya pengaruh variabel bebas terhadap variabel terikat disebut koefisien jalur.

Menurut Pedhazur (1982) dalam Marwan Hamid, dkk (2019), bahwa tujuan analisis jalur adalah apakah model yang diusulkan cocok atau tidak dengan data, yaitu dengan membandingkan matriks korelasi teoritis dengan matriks korelasi empiris. Jika kedua matriks relatif sama, maka model dikatakan "cocok" atau fit. Analisis jalur ialah suatu teknik untuk menganalisis hubungan sebab-akibat yang terjadi pada regresi berganda jika variabel bebasnya mempengaruhi variabel tergantungnya tidak hanya secara langsung, tetapi juga secara tidak langsung" (Robert D. Rutherford, 1993, dalam Marwan Hamid, dkk; 2019:10). Definisi lain mengatakan "Analisis jalur merupakan pengembangan langsung bentuk regresi berganda dengan tujuan untuk memberikan estimasi tingkat kepentingan (magnitude) dan signifikansi (significance) hubungan sebab-akibat hipotetikal dalam seperangkat variabel" (Paul Webley; 1997, dalam Marwan, dkk; 2019).

Menurut Marwan, dkk (2019:10), model analisis jalur digunakan untuk menganalisis pola hubungan antar variabel dengan tujuan untuk mengetahui pengaruh langsung maupun tidak langsung seperangkat variabel bebas (eksogen) terhadap variabel terikat (endogen). Model analisis jalur yang dibicarakan adalah pola hubungan sebab-akibat. Oleh karena itu, rumusan masalah penelitian dalam kerangka analisis jalur hanya berkisar pada variabel bebas $\left(\mathrm{X}_{1}, \mathrm{X}_{2}, \ldots, \mathrm{X}_{\mathrm{k}}\right)$ yang berpengaruh terhadap variabel terikat $\mathrm{Y}$ atau berapa besar pengaruh kausal langsung, kausal tidak langsung, kausal total maupun simultan seperangkat variabel bebas $\left(\mathrm{X}_{1}, \mathrm{X}_{2}, \ldots, \mathrm{X}_{\mathrm{k}}\right)$ terhadap variabel terikat $\mathrm{Y}$.

Sebelum melakukan analisis, ada beberapa prinsip dasar atau asumsi yang mendasari analisis jalur, yaitu:

1) Pada model analisis jalur, hubungan antar variabel adalah bersifat linier, adaptif, dan bersifat normal.

2) Hanya sistem aliran kausal ke satu arah, artinya tidak ada arah kausalitas yang berbalik.

3) Variabel terikat (endogen), minimal dalam skala ukur interval dan ratio. 
4) Menggunakan sampel probability sampling, yaitu teknik pengambilan sampel untuk memberikan peluang yang sama pada setiap anggota populasi untuk dipilih menjadi anggota sampel.

5) Variabel observasi diukur tanpa kesalahan (instrumen pengukuran valid danreliabel), artinya variabel yang diteliti dapat diobservasi secara langsung.

6) Model yang dianalisis dispesifikasikan dengan benar berdasarkan teori-teori dan konsep-konsep yang relevan, artinya model teori yang dikaji atau diuji dibangun berdasarkan kerangka teoritis tertentu yang mampu menjelaskan hubungan kausalitas antar variabel yang diteliti. (Marwan, dkk; 2019:12).

\section{Hasil dan Pembahasan (Results and Discussion)}

\section{a. Hasil Penelitian}

1). Uji Validitas dari Intrumen Penelitian

Berikut dihasilkan uji validitas intrumen semua variabel penelitian, yakni:

Tabel 2. Uji Coba Validitas Instrumen untuk Variabel Motivasi $\mathrm{X}_{1}$ )

\begin{tabular}{|c|l|c|c|}
\hline Butir & \multicolumn{1}{|c|}{ Pernyataan } & r-hitung & Keputusan \\
\hline 1 & $\begin{array}{l}\text { Umumnya guru memiliki Tanggung jawab terhadap semua pekerjaannya, } \\
\text { khususnya meningkatkan mutu sekolah }\end{array}$ & 0,342 & Valid \\
\hline 2 & Tidak semua guru memiliki minat terhadap pekerjaannya & 0,128 & Tidak Valid \\
\hline 3 & Guru memahami profesinya sehingga selalu mencapai Kepuasan dalam bekerja & 0,484 & Valid \\
\hline 4 & Guru termotivasi bekerja, karena adanya kebutuhan yang harus dipenuhinya & 0,781 & Valid \\
\hline 5 & Guru selalu tampak bersemangat dalam bekerja & 0,450 & Valid \\
\hline 6 & $\begin{array}{l}\text { Guru merasa termotivasi karena memperoleh pujian atau perhatian dari orang } \\
\text { lain }\end{array}$ & 0,684 & Valid \\
\hline 7 & Timhulnya motivasi guru karena ingin mendapatkan insentif/imbalan & 0,796 & Valid \\
\hline 8 & Umumnya guru bekeinginan untuk mendapatkan penghargaan atau prestasi & 0,632 & Valid \\
\hline 9 & Guru termotivasi terus, karena adanya Dorongan dari atasan (Kepala Sekolah) & 0,512 & Valid \\
\hline 10 & $\begin{array}{l}\text { Munculnya semangat kerja guru akibat adanya hubungan antar pribadi guru itu } \\
\text { sendiri }\end{array}$ & 0,730 & Valid \\
\hline 11 & Kondisi kerja memberikan dukungan utk guru bekerja giat dan rajin & 0,522 & Valid \\
\hline
\end{tabular}

Dari hasil perhitungan validitas variabel motivasi, hasil $r$-hitung dibandingkan dengan $r$-min $=0,300$, maka terdapat 1 butir yang tidak valid, yakni butir nomor 2 karena nilai r-hitung $<0,3000$. Sedangkan lainnya terdapat 10 butir atau item pernyataan yang mengukur variabel motivasi dinyatakan valid untuk dipakai sebagai penelitian.

Tabel 3. Uji Coba Validitas Instrumen untuk Variabel Kompensasi $\left(\mathrm{X}_{2}\right)$

\begin{tabular}{|c|l|c|c|}
\hline Butir & \multicolumn{1}{|c|}{ Pernyataan } & r-hitung & Keputusan \\
\hline 1 & Gaji guru sudah sesuai dengan status dan jabatannya, dan mencukupi kebutuhan & 0,416 & Valid \\
\hline 2 & $\begin{array}{l}\text { Guru akan juga mendapat Bonus atas prestasinya, dan hal ini penting untuk } \\
\text { kepuasan kerja }\end{array}$ & 0,461 & Valid \\
\hline 3 & Insentif guru mampu mememuaskan kerja mereka untuk terus meningkat & 0,627 & Valid \\
\hline 4 & Fasilitas kerja guru dapat memuaskan kerja mereka & 0,637 & Valid \\
\hline 5 & $\begin{array}{l}\text { Lingkungan kerja sangat mendukung untuk guru mampu berprestasi dan puas } \\
\text { dalam bekerja }\end{array}$ & 0,681 & Valid \\
\hline 6 & $\begin{array}{l}\text { Penghargaan yang diterima guru, layak dan sesuai dengan apa yang } \\
\text { disumbangkannya dalam meningkatkan diri dan mutu sekolah }\end{array}$ & 0,578 & Valid \\
\hline
\end{tabular}

Dari hasil perhitungan validitas variabel kompensasi, hasil r-hitung dibandingkan dengan $r$-min $=0,300$, maka tampak hasilnya semua butir atau item pernyataan variabel kompensasi ini dinyatakan valid, karena nilai r-hitung paling kecil 0,416 dan yang terbesar 0,681, semua diatas 0,300. Sehingga semua butir pernyataan dapat digunakan untuk mengukur variabel kompensasi dalam penelitian ini.

Tabel 4. Uji Coba Validitas Instrumen untuk Variabel Iklim Organisasi $\left(\mathrm{X}_{3}\right)$

\begin{tabular}{|c|l|c|c|}
\hline Butir & \multicolumn{1}{|c|}{ Pernyataan } & r-hitung & Keputusan \\
\hline 1 & $\begin{array}{l}\text { Sarana fisik dalam lingkungan sekolah sangat mem-bantu meningkatkan } \\
\text { komitmen guru berprestasi }\end{array}$ & 0,799 & Valid \\
\hline 2 & Prasarana dalam proses kerja sangat meuaskan guru dalam berkarya & 0,704 & Valid \\
\hline 3 & Hubungan pertemanan diantara guru atau collegial terjalin harmonis dan normati & 0,580 & Valid \\
\hline 4 & $\begin{array}{l}\text { Kedekatan antara sesama guru dan siswa serta wali siswa sangat baik dan saling } \\
\text { mendukung }\end{array}$ & 0,628 & Valid \\
\hline 5 & $\begin{array}{l}\text { Hubungan sesama guru dan tenaga kependidikan saling mendukung dalam } \\
\text { mencapai tujuan sekolah. }\end{array}$ & 0,656 & Valid \\
\hline
\end{tabular}


Dari hasil perhitungan validitas variabel iklim organisasi, hasil r-hitung dibandingkan dengan $\mathrm{r}$-min $=$ 0,300 , maka tampak hasilnya semua butir atau item pernyataan variabel iklim organisasi ini dinyatakan valid, karena nilai r-hitung paling kecil 0,580 dan yang terbesar 0,799, semua diatas 0,300 . Sehingga semua butir pernyataan dapat digunakan untuk mengukur variabel iklim organisasi dalam penelitian ini.

Tabel 5. Uji Coba Validitas Instrumen untuk Variabel Kepuasan Guru (Y)

\begin{tabular}{|c|l|c|c|}
\hline Butir & \multicolumn{1}{|c|}{ Pernyataan } & r-hitung & Keputusan \\
\hline 1 & Kemampuan guru umumnya memenuhi standar kompetensi yang diharapkan & 0,705 & Valid \\
\hline 2 & Ketelitian dalam bekerja selalu diperbuat oleh guru & 0,512 & Valid \\
\hline 3 & Waktu mengajar dimanfaatkan dengan baik dan rasa percaya diri & 0,851 & Valid \\
\hline 4 & Kehadiran guru umumnya sangat baik, sesuai aturan yang diterapkan sekolah & 0,882 & Valid \\
\hline 5 & Tata Tertib terhadap guru dengan senang hati dilakoni oleh guru & 0,850 & Valid \\
\hline 6 & Guru umumnya berinisiatif untuk memberi Gagasan yang cemerlang & 0,703 & Valid \\
\hline 7 & Kreatifivitas guru umumnya mampu mewarnai kemajuan sekolah & 0,751 & Valid \\
\hline 8 & $\begin{array}{l}\text { Komunikasi Interpersonal guru dengan siswa sangat terjaga dan selalu berjalan } \\
\text { harmonis }\end{array}$ & 0,788 & Valid \\
\hline 9 & $\begin{array}{l}\text { Komunikasi Eksternal guru dengan pihak lain sangat baik dan tidak menjadi } \\
\text { hambatan untuk eksistensi guru di masyarakat }\end{array}$ & 0,669 & Valid \\
\hline
\end{tabular}

Dari hasil perhitungan validitas variabel kepuasan guru, hasil r-hitung dibandingkan dengan $r$-min $=0,300$, maka tampak hasilnya semua butir atau item pernyataan variabel kepuasan guru ini dinyatakan valid, karena nilai r-hitung paling kecil 0,512 dan yang terbesar 0,882 , semua diatas 0,300 . Sehingga semua butir pernyataan dapat digunakan untuk mengukur variabel iklim organisasi dalam penelitian ini.

\section{2). Uji Reliabilitas Instrumen Penelitian}

Sedangkan untuk pengujian realibilitas instrument dihitung dengan menggunakan rumus koefisien Cronbach Alpha $(\alpha)$, . Uji reliabilitas diperlukan untuk mengetahui tingkat kekonsistenan alat ukur yang dipakai. Alat ukur dapat dikatakan reliable (dapat dipercaya), bila hasil pengukurannya tetap atau nilai yang diperoleh konsisten, walaupun dilakukan pengukuran ulang pada subyek yang sama (Sugiono; 2005:85).

Pengujian reliabilitas terhadap seluruh item/pertanyaan yang dipergunakan pada penelitian ini akan menggunakan formula Cronbach Alpha ( $\alpha$ ), dimana secara umum dianggap reliabel apabila nilai $\alpha>0,65$, jika Nilai koefisien reliabilitas yang baik adalah diatas 0,7 (cukup baik), di atas 0,8 (baik). (Sudjana, 2005:369.). Hasil uji reliabilitas semua variabel ditunjukkan tabel berikut:

Tabel 6. Hasil Uji Reliabilitas Instrumen Variabel

\begin{tabular}{|cl|c|c|c|}
\hline \multicolumn{1}{|c|}{ Variabel } & Cronbach's Alpha & N of Items & Keterangan \\
\hline- & Motivasi guru & 0,814 & 10 & Reliable \\
\hline- & Kompensasi & 0,715 & 6 & Reliable \\
\hline- & Iklim organisasi & 0,699 & 5 & Reliable \\
\hline- & Kepuasan guru & 0,902 & 9 & Reliable \\
\hline
\end{tabular}

Sumber : Hasil Uji coba Peneltian, 2020

Menurut Sekaran (2006), bahwa reabilitas yang kurang dari 0,6 adalah kurang baik, sedangkan 0,7 dapat diterima dan reliabilitas dengan Cronbach's Alpha 0,8 atau di atasnya adalah lebih baik. Berdasarkan output yang diperoleh dari tabel di atas, diperoleh nilai koefisien reliabilitas pada semua variabel adalah realiable, dan hasilnya tinggi, karena koefisien reliabilitas pada variabel lebih besar dari 0,6 , maka variabelvariabel yang digunakan pada instrumen tersebut adalah reliabel untuk digunakan dalam penelitian.

\section{b. Analisis Deskriptif}

Analisis deskriptif di bawah menunjukkan gambaran mengenai suatu data yang akan diteliti atau untuk menguraikan kecenderungan jawaban responden dari tiap-tiap variabel. Berdasarkan hasil kuesioner yang telah teruji validitas dan reliabilitasnya, dan dari 184 guru pada SMK di Kabupaten Bireuen, diperoleh jawaban terhadap variabel bebas Motivasi, Kompensasi, Iklim organisasi, dan Kepuasan guru sebagai berikut.

Berdasarkan tabel 7, dapat dijelaskan bahwa:

1. Variabel motivasi guru, menurut persepsi guru di SMK di Kabupaten Bireuen, sudah baik, mencapai $82,55 \%$ waluapun masih harus dioptimalkan lagi.

2. Variabel Kompensasi dianggap oleh sebagain guru sudah baik dalam mendukung kepuasan kerja. Skor penilaian guru atas kompensasi mencapai $82,36 \%$, 
3. Variabel Iklim organisasi, faktor penting juga kepuasan guru, menurut penilaian guru, juga belum mendekati optimal, baru mencapai $87,56 \%$, dan

4. Tingkat Kepuasan guru mencapai kategori baik, yakni .83,57\%.

Tabel 7. Deskripsi Guru tentang Variabel Penelitian

\begin{tabular}{|c|c|c|c|c|c|c|}
\hline \multirow{2}{*}{ Variabel } & \multicolumn{5}{|c|}{ Persentase Jawaban setiap item (Jumlah) } & \multirow{2}{*}{$\begin{array}{c}\text { Skor } \\
\text { Pencapaian }\end{array}$} \\
\hline & STS & TS & KS & $\mathrm{S}$ & SS & \\
\hline - Motivasi guru & $\begin{array}{c}0,00 \\
(0)\end{array}$ & $\begin{array}{l}2,12 \\
(39)\end{array}$ & $\begin{array}{l}15,00 \\
(276)\end{array}$ & $\begin{array}{l}50,87 \\
(936)\end{array}$ & $\begin{array}{l}32,01 \\
(589)\end{array}$ & 82,55 \\
\hline - Kompensasi & $\begin{array}{c}0,00 \\
(0)\end{array}$ & $\begin{array}{l}1,90 \\
(21)\end{array}$ & $\begin{array}{l}12,86 \\
(142)\end{array}$ & $\begin{array}{l}56,79 \\
(627)\end{array}$ & $\begin{array}{l}28,44 \\
(314)\end{array}$ & 82,36 \\
\hline - Iklim organisasi & $\begin{array}{r}0,00 \\
(0) \\
\end{array}$ & $0,00(0)$ & $\begin{array}{l}4,78 \\
(44) \\
\end{array}$ & $\begin{array}{l}52,61 \\
(484) \\
\end{array}$ & $\begin{array}{l}42,61 \\
(392) \\
\end{array}$ & 87,56 \\
\hline - Kepuasan guru & $\begin{array}{c}0,00 \\
(0)\end{array}$ & $0,00(0)$ & $\begin{array}{l}12,14 \\
(201)\end{array}$ & $\begin{array}{l}57,85 \\
(958)\end{array}$ & $\begin{array}{l}30,01 \\
(497)\end{array}$ & $\mathbf{8 3 , 5 7}$ \\
\hline
\end{tabular}

Sumber : Hasil Peneltian, 2020 (data diolah dengan spss)

\section{c. Pengujian Asumsi Klasik dalam Penggunaan Alat Analisis Statistik}

Sebelum melakukan alat analisis statistik, yakni analisis jalur, dan pengujian hipotesis, terlebih dahulu dilakukan pengujian asumsi klasik yang bertujuan untuk memastikan bahwa model jalur yang digunakan dalam analisis masalah dapat digunakan atau tidak. Apabila uji asumsi klasik telah terpenuhi, maka alat uji statistik analisis jalur dapat dipergunakan.

\section{- Uji Normalitas}

Hasil Pengujian Normalitas dapat dilihat pada gambar 1. Dari grafik kurva normal, dapat disimpulkan bahwa data yang digunakan menunjukkan normal. Singgih Santoso (2009:342) menyatakan bahwa jika data menyebar normal di sekitar garis diagonal dan mengikuti arah garis diagonal, maka model regresi memenuhi asumsi normalitas. Sebaliknya jika data menyebar jauh dari garis diagonal, maka model regresi tidak memenuhi asumsi normalitas. Uji normalitas dilakukan untuk mengetahui simetris tidaknya distribusi data.

\section{Normal P-P Plot of Regression Standardized} Residual

Scatterplot

Dependent Variable: Kepuasan Guru

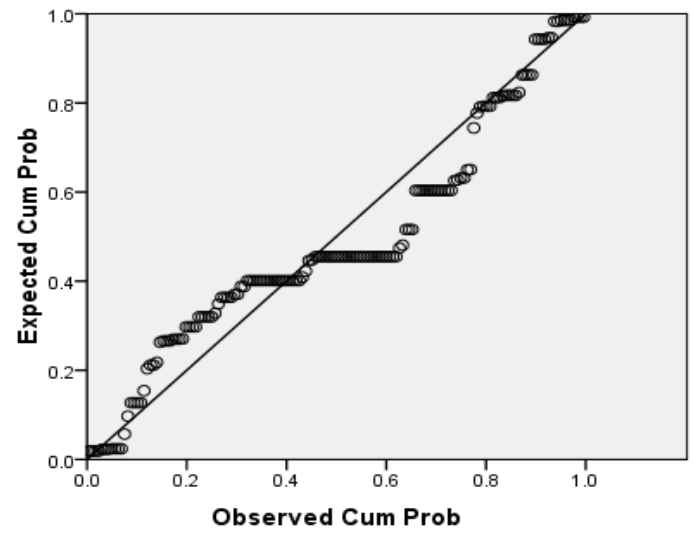

Gambar 1. Uji Normalitas

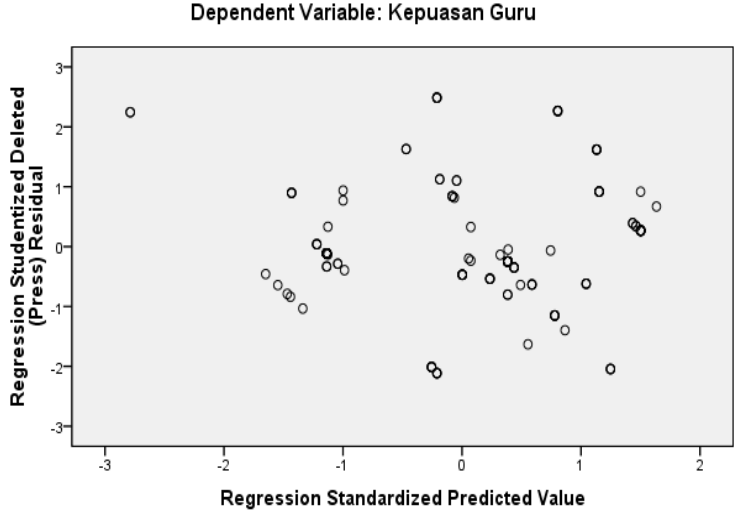

Gambar 2. Uji Heterokedastisitas

\section{- Uji Heterokedastisitas}

Uji heterokedatisitas dilakukan untuk mengetahui penyebaran varians gangguan. Hasil pengujian heterokedatisitas data dalam penelitian ini menggunakan alat bantu SPSS dengan mengamati pola pada scatterplot, hasilnya dapat dilihat pada gambar 2 diatas, terlihat bahwa titik-titik menyebar secara acak (random) serta tersebar di atas maupun di bawah angka 0 pada sumbu $Y$, sehingga dapat disimpulkan bahwa tidak terjadi heterokedastisitas pada model regresi dan layak dipakai untuk memprediksi keputusan memilih berdasarkan masukan dari variabel bebasnya. 


\section{- Uji Multikolinearitas}

Uji Multikolinearitas Menurut Santoso (2009) suatu model regresi dikatakan bebas dari masalah tersebut jika nilai Variance Inflation Factor (VIF) dan Tolerance adalah: Mempunyai nilai Variance Inflation Factor di bawah 10, Mempunyai angka Tolerance diatas 0, dan besaran korelasi antar variabel independen haruslah lemah $<5$ (di bawah 0,5).

Uji multikollinieritas dilakukan untuk mengetahui ada tidaknya korelasi antar varibel bebas yang disebut dengan multikolonieritas. Pada model regresi yang baik tidak terjadi korelasi di antara variabel bebas. Hasil pengujian multikollinieritas data dalam penelitian ini menggunakan alat bantu SPSS, hasilnya dapat dilihat pada tabel berikut :

Tabel 8. Hasil Uji Multikolinearitas

\begin{tabular}{|c|c|c|c|c|c|}
\hline \multirow[b]{2}{*}{ Model } & \multirow{2}{*}{$\begin{array}{c}\begin{array}{c}\text { Standardized } \\
\text { Coefficients }\end{array} \\
\text { Beta }\end{array}$} & \multirow[b]{2}{*}{$\mathrm{t}$} & \multirow[b]{2}{*}{ Sig. } & \multicolumn{2}{|c|}{ Collinearity Statistics } \\
\hline & & & & Tolerance & VIF \\
\hline \multirow{4}{*}{$\begin{array}{l}\text { (Constant) } \\
\text { Motivasi } \\
\text { Kompensasi } \\
\text { Iklim Organisasi }\end{array}$} & & -3.411 & .001 & & \\
\hline & .112 & 2.102 & .024 & .516 & 1.746 \\
\hline & .181 & 2.390 & .012 & .237 & 3.726 \\
\hline & .647 & 8.047 & .000 & .226 & 4.234 \\
\hline
\end{tabular}

Sumber : Hasil Peneltian, 2020 (data diolah dengan spss)

Dari tabel 8 dapat dilihat bahwa variabel bebas yang memiliki nilai Variance Inflation Factor dibawah 10 dan mempunyai angka Tolerance diatas 0. Jadi dapat disimpulkan bahwa tidak ada multikollinieritas antar variabel bebas dalam model regresi.

\section{d. Hasil Analisis Jalur}

Data penelitian terhadap 184 guru SMK di Kabupaten Bireuen, dengan instrumen yang telah teruji validitas dan reliabilitasnya. Hasil pendataan ditunjukkan dalam Lampiran-3A. Untuk menganalisis Model dengan pendekatan kuantitatif berdasarkan analisis Jalur, maka pertama harus ditransformasi data dari angket yang berskala ordinal, dalam bentuk Interval dengan metode susesiv interval, lalu diolah dengan program Spss.

Dalam penelitian ini model analisis dengan analisi jalur yang menentukan pengaruh variabel Motivasi $\left(\mathrm{X}_{1}\right)$, Kompensasi $\left(\mathrm{X}_{2}\right)$, dan Iklim organisasi $\left(\mathrm{X}_{3}\right)$ terhadap Kepuasan guru $(\mathrm{Y})$ pada guru SMK di Kabupaten Bireuen. Dengan model $Y=\rho_{1} X_{1}+\rho_{2} X_{2}+\rho_{3} X_{3}+e$.

\section{- Uji Model secara Simultan}

Adapun pembuktian hipotesis secara simultan (keseluruhan) dapat dilihat pada tabel berikut ini:

Tabel 9. Uji Model Analisis Secara Simultan

\begin{tabular}{|l|r|r|r|r|r|}
\hline Model & Sum of Squares & \multicolumn{1}{c|}{ df } & Mean Square & F & \multicolumn{1}{c|}{ Sig. } \\
\hline Regression & 4636.852 & 3 & 1545.617 & 191.500 & $.000^{\mathrm{a}}$ \\
\cline { 2 - 6 } $\begin{array}{l}\text { Residual } \\
\text { Total }\end{array}$ & 1452.800 & 180 & 8.071 & & \\
\cline { 2 - 7 } & 6089.652 & 183 & & & \\
\hline
\end{tabular}

Predictors: (Constant), Iklim Org, Motivasi, Kompensasi, Dependent Variable: Kepuasan

Berdasarkan hasil uji $\mathrm{F}$ diperoleh nilai $\mathrm{F}_{\text {hitung }}$ sebesar 191,500 sementara nilai $\mathrm{F}_{\text {tabel }}$ untuk jumlah responden sebanyak 184 orang $(\mathrm{N}=184)$ pada tingkat signifikansi $(\alpha)=5 \%$ yaitu sebesar 2,72 . Hal ini menunjukkan bahwa $F_{\text {hitung }}>F_{\text {tabel }}$ dengan tingkat signifikansi 0,05. Hal ini juga tampak dalam kolom-6 tabel 9 diatas, yang menyatakan nilai signifikansinya pada 0.000 . Dengan demikian dapat disimpulkan bahwa probabilitas dalam penelitian ini lebih kecil dari 0,05\% maka hipotesis nol (Ho) ditolak, yang berarti bahwa variabel Motivasi $\left(\mathrm{X}_{1}\right)$, Kompensasi $\left(\mathrm{X}_{2}\right)$, dan Iklim organisasi $\left(\mathrm{X}_{3}\right)$ terhadap Kepuasan guru $(\mathrm{Y})$ pada guru SMK di Kabupaten Bireuen.

\section{- Pengujian Hipotesis Penelitan}

Selanjutnya dilakukan pengujian hipotesis yang diajukan selanjutnya diuji untuk menjawab masalah penelitian yang dirumuskan. Kemudian dilanjutkan dengan pengujian model yang dihipotesiskan, menentukan pengaruh langsung dan tidak langsung, selanjutnya pembahasan hasil penelitian.

Berdasarkan hipotesis penelitian, dibangkitkan model diagram jalur beserta nilai koefisien jalur dan koefisien kausal antar variabel eksogen, yang dinyatakan dalam tabel 10 dan gambar 3. 
Tabel 10. Pengujian signifikansi Koefisien Regresi (Model secara Parsial)

\begin{tabular}{|c|c|c|c|c|}
\hline \multirow[b]{2}{*}{ Model } & Standardized Coefficients & \multirow[b]{2}{*}{$\mathrm{t}$} & \multirow[b]{2}{*}{ Sig. } & \multirow[b]{2}{*}{ Keputusan } \\
\hline & Beta & & & \\
\hline \multirow{4}{*}{$\begin{array}{l}\text { (Constant) } \\
\text { Motivasi } \\
\text { Kompensasi } \\
\text { Iklim Organisasi }\end{array}$} & & -3.411 & .001 & \\
\hline & .112 & 2.102 & .024 & Signifikan \\
\hline & .181 & 2.390 & .012 & Signifikan \\
\hline & .647 & 8.047 & .000 & Signifikan \\
\hline
\end{tabular}

Dan juga dari tabel 10 menunjukkan bahwa:

1). Variabel Motivasi dalam model jalur yang diasumsikan, signifikans pada taraf uji $2,4 \%$ (sig $=$ $0,024)$;

2). Variabel Kompensasi dalam model jalur yang diasumsikan, signifikans pada taraf uji sebesar 1,2\% $(\operatorname{sig}=0,012)$

3). Dan variabel Iklim Organisasi dalam model jalur yang diasumsikan, signifikans pada taraf uji $0 \%$ (sig = 0,000);

4). Atas dasar ketiga variabel bebas (Motivasi, Kompensasi, dan Iklim organisasi) secara parsial berpengaruh terhadap kepuasan guru, maka secara simultan melalui uji-F sudah diyakini ketiga variabel tersebut bersama-sama berpengaruh terhadap kepuasan guru.

Dimana model jalurnya digmbarkan berikut ini:

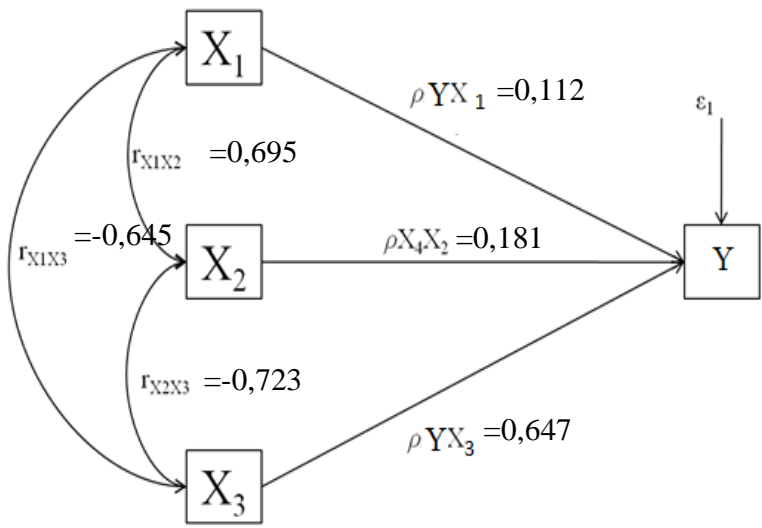

Keterangan :

$\mathrm{Y}=$ Kepuasan guru

$\mathrm{X} 1$ = Motivasi

$\mathrm{X} 2=$ Kompensasi

$\mathrm{X} 3$ = Iklim organisasi

$\mathrm{r}_{\mathrm{xi}, \mathrm{xj}}=$ hubungan kausal antar variabel eksogen di ukur dengan koefisien korelasi

$\rho_{\text {yxi }}=$ Nilai Koefisien Jalur (Path) yang menyatakan pengaruh langsung antar variabel eksogen terhadap variable endogen.

Gambar 3. Diagram Jalur Penelitian

\section{d. Pembahasan}

\section{1). Pengaruh Motivasi guru terhadap Kepuasan guru}

Berdasarkan gambar 3 diagram jalur diatas, maka :

Besarnya pengaruh langsung Motivasi guru $\left(\mathrm{X}_{1}\right)$ terhadap Kepuasan guru $(\mathrm{Y})$, dinyatakan dengan besaran koefisien jalur $\left(\rho_{\mathrm{yx} 1}=0,112\right)$, Sehingga besarnya pengaruh langsung ini adalah: $(0,112)^{2} \times 100 \%=1,25 \%$.

Besarnya pengaruh tak langsung Motivasi guru $\left(\mathrm{X}_{1}\right)$ terhadap Kepuasan guru $(\mathrm{Y})$, karena adanya hubungan kausal motivasi dengan Kompensasi $\left(\mathrm{X}_{2}\right)$ dan Iklimorganisasi sekolah $\left(\mathrm{X}_{3}\right)$, dinyatakan dengan besaran koefisien jalur, dan koefisien korelasi dari hubungan antar variabel dimaksud, sehingga di hitung sebegai berikut:

- Pengaruh Motivasi $\left(\mathrm{X}_{1}\right)$ melalui kompensasi $\left(\mathrm{X}_{2}\right)$ terhadap Kepuasan guru $(\mathrm{Y})$, adalah = $(0,112)(0,695)(0,181) \times 100 \%=1,41 \%$

- Pengaruh Motivasi $\left(\mathrm{X}_{1}\right)$ melalui iklim organisasi sekolah $\left(\mathrm{X}_{3}\right)$ terhadap Kepuasan guru $(\mathrm{Y})$ adalah = $(0,112)(0,645)(0,647) \times 100 \%=4,67 \%$

Berdasarkan hal diatas, maka dapat dihitung besarnya pengaruh total Motivasi $\left(\mathrm{X}_{1}\right)$ terhadap Kepuasan guru (Y), yakni: $1,25 \%+1,41 \%+4,67 \%=7,34 \%$. 


\section{2). Pengaruh Kompensasi terhadap Kepuasan guru}

Besarnya pengaruh langsung Kompensasi $\left(\mathrm{X}_{2}\right)$ terhadap Kepuasan guru $(\mathrm{Y})$, dinyatakan dengan besaran koefisien jalur $\left(\rho_{\mathrm{y} \times 2}=0,181\right)$, Sehingga besarnya pengaruh langsung ini adalah: $(0,181)^{2} \times 100 \%=3,46 \%$.

Besarnya pengaruh tak langsung Kompensasi $\left(\mathrm{X}_{2}\right)$ terhadap Kepuasan guru $(\mathrm{Y})$, karena adanya hubungan kausal Kompetensi dengan motivasi $\left(\mathrm{X}_{1}\right)$ dan Iklim organisasi sekolah $\left(\mathrm{X}_{3}\right)$, dinyatakan dengan besaran koefisien jalur, dan koefisien korelasi, sehingga di hitung sebagai berikut:

- Pengaruh Kompensasii $\left(\mathrm{X}_{2}\right)$ melalui motivasi $\left(\mathrm{X}_{1}\right)$ terhadap Kepuasan guru $(\mathrm{Y})$, adalah = $(0,181)(0,695)(0,112) \times 100 \%=1,41 \%$

- Pengaruh Kompensasi $\left(\mathrm{X}_{2}\right)$ melalui iklim organisasi sekolah $\left(\mathrm{X}_{3}\right)$ terhadap Kepuasan guru $(\mathrm{Y})$ adalah = $(0,181)(0,723)(0,647) \times 100 \%=8,47 \%$

Berdasarkan pengaruh langsung dan tidak langsung, maka dapat dihitung besarnya pengaruh total Kompensasi $\left(\mathrm{X}_{2}\right)$ terhadap Kepuasan guru $(\mathrm{Y})$, yakni : 3,46 \% + 1,41 \% + 8,47 \% $=\mathbf{1 3 , 3 3} \%$.

\section{3). Pengaruh Iklim Organisasi terhadap Kepuasan guru}

Besarnya pengaruh langsung iklim organisasi $\left(\mathrm{X}_{3}\right)$ terhadap Kepuasan guru $(\mathrm{Y})$, dinyatakan dengan besaran koefisien jalur $\left(\rho_{\mathrm{yx} 3}=0,647\right)$, Sehingga besarnya pengaruh langsung ini adalah: $(0,647)^{2} \times 100 \%=\mathbf{4 1 , 8 6 \%}$.

Besarnya pengaruh tak langsung Iklim organisasi $\left(\mathrm{X}_{3}\right)$ terhadap Kepuasan guru $(\mathrm{Y})$, karena adanya hubungan kausal Iklim organisasi dengan motivasi $\left(\mathrm{X}_{1}\right)$ dan Kompensasi (X2), dinyatakan dengan besaran koefisien jalur, dan koefisien korelasi, sehingga di hitung sebagai berikut:

- Pengaruh Iklim organisasi $\left(\mathrm{X}_{3}\right)$ melalui motivasi $\left(\mathrm{X}_{1}\right)$ terhadap Kepuasan guru $(\mathrm{Y})$, adalah = $(0,647)(0,645)(0,112) \times 100 \%=4,67 \%$

- Pengaruh Iklim organisasi $\left(\mathrm{X}_{3}\right)$ melalui kompensasi $\left(\mathrm{X}_{2}\right)$ terhadap Kepuasan guru $(\mathrm{Y})$ adalah $=$ $(0,647)(0,723)(0,181) \times 100 \%=8,47 \%$

Berdasarkan pengaruh langsung dan tidak langsung, maka dapat dihitung besarnya pengaruh total Iklim organisasi $\left(\mathrm{X}_{2}\right)$ terhadap Kepuasan guru $(\mathrm{Y})$, yakni : 41,86 \% + 4,67 \% + 8,47 \% $=55,00 \%$.

\section{4). Analisis Pengaruh Variabel Motivasi, Kompensasi, dan Iklim Organisasi terhadap Kepuasan Guru SMK se- Kabupaten Bireuen}

Berdasarkan pengujian model jalur di atas maka dapat dituliskan persamaan untuk model jalur adalah sebagai berikut: $\mathrm{Y}=\rho_{\mathrm{Yx} 1}+\rho_{\mathrm{Yx} 2}+\rho_{\mathrm{Yx} 3}+\varepsilon_{1}=0,112 \mathrm{X}_{1}+0,181 \mathrm{X}_{2}+0,647 \mathrm{X}_{3}$

Dimana : $Y=$ Kepuasan, $X_{1}=$ Motivasi, $X_{2}=$ Kompensasi, $X_{3} \quad=$ Iklim Organisasi, $\rho=$ Koefisien Jalur

Maka dari persamaan tersebut dapat dijelaskan bahwa koefisien jalur Koefisien Motivasi $\left(\mathrm{X}_{1}\right)$ bernilai positif $(0,112)$ artinya apabila motivasi guru diupayakan baik akan dapat mendukung kepuasan guru dalam bekerja.

Untuk variabel kompensasi $\left(\mathrm{X}_{2}\right)$ juga bernilai positif $(0,181)$ artinya semakin baik guru memperoleh kompensasi dalam kebutuhan hidupnya maka guru SMK se-Kabupaten Bireuen, akan menrasa puas bekerja

Koefisien jalur Iklim organisasi Sekolah $\left(\mathrm{X}_{3}\right)$ bernilai positif $(0,647)$ artinya apabila iklim organisasi di sekolah sesuai harapan guru dan mendukung kerja guru, maka secara otomatid meningkatkan Kepuasan guru.

Selain menguji koefisien regresi, penelitian ini juga menguji koefisien korelasi (R) dan koefisien determinasi $\left(\mathrm{R}^{2}\right)$. Koefisien korelasi bertujuan untuk melihat keeratan hubungan antara satu variabel dengan variabel lain. Sementara korelasi determinasi $\left(\mathrm{R}^{2}\right)$ mengukur seberapa jauh kemampuan variabel-variabel independen dalam menjelaskan variasi variabel dependen (Ghozali, 2012).

Maka analisis koefisien korelasi dan determinasi variabel bebas (X) dengan variabel terikat (Y) yang dapat dilihat dari tabel berikut:

Tabel 11. Koeisien Korelasi Simultan

\begin{tabular}{|c|c|c|c|}
\hline $\mathrm{R}$ & R Square & Adjusted R Square & Std. Error of Estimate \\
\hline $.873^{\mathrm{a}}$ & .761 & .757 & 2.840970 \\
\hline
\end{tabular}

Hasil analisis koefisien korelasi antara Motivasi, Kompensasi, dan Iklim organisasi Sekolah terhadap Kepuasan guru SMKN se-Kabupaten Bireuen diperoleh $R$ sebesar 0,880 menjelaskan hubungan antara 
Motivasi, Kompensasi, dan Iklim organisasi Sekolah terhadap Kepuasan guru, memiliki keeratan yang cukup tinggi, dan berhubungan secara linier, dengan derajat hubungannya sebesar 0,873.

Nilai koefisien determinasi sebesar 0,775 menjelaskan bahwa kontribusi faktor Motivasi, Kompensasi, dan Iklim organisasi Sekolah terhadap Kepuasan SMKN se Kabupaten Bireuen sebesar 76,1 \%. Sementara sisanya (nilai residu) dari peran variabel yang tidak diteliti sebesar 23,9\%. Nilai residu tersebut menujukkan bahwa terdapat faktor-faktor lain yang dapat mempengaruhi variabel Kepuasan guru SMKN se-Kabupaten Bireuen, seperti Kepemimpinan Kepala Sekolah, Budaya organisasi, fasilitas kerja, Pendidikan dan Pelatihan, dan lain-lain..

\section{Simpulan dan Saran (Conclusions and Suggestions)}

\section{a. Simpulan (Conclusion)}

Berdasarkan pembahasan hasil penelitian maka ditarik simpulan sebagai berikut :

1) Hasil analisis, menunjukkan adanya pengaruh faktor Motivasi guru terhadap Kepuasan guru SMK Negeri se-Kabupaten Bireuen, yakni 7,34\%.

2) Hasil analisis data juga membuktikan adanya pengaruh faktor Kompensasi terhadap Kepuasan guru SMK Negeri se-Kabupaten Bireuen, yakni 13,33\%.

3) Dan dari hasil analisis selanjutnya, menunjukkan adanya pengaruh Iklim organisasi sekolah terhadap Kepuasan guru SMK Negeri se-Kabupaten Bireuen, yakni 55,00\%.

4) Hasil analisis deskriptif, menemukan bahwa, a). motivasi guru di SMK di Kabupaten Bireuen, sudah baik, mencapai $82,55 \%$ walaupun masih harus dioptimalkan lagi. b). Variabel Kompensasi dianggap oleh sebagain guru sudah baik dalam mendukung kepuasan kerja. Skor penilaian guru atas kompensasi mencapai $82,36 \%$, dan c). Variabel Iklim organisasi, faktor penting juga kepuasan guru, menurut penilaian guru, juga hampir mendekati optimal, baru mencapai 87,56\%. Dan d). Tingkat Kepuasan guru mencapai kategori baik, yakni 83,57\%.

5) Hasil analisis dari nilai koefisien determinasi menjelaskan bahwa kontribusi faktor Motivasi kerja, Kompensasi dan Iklim organisasi terhadap Kepuasan guru SMK negeri se-Kabupaten Bireuen sebesar $76,1 \%$. Sementara sisanya (nilai residu) dari peran variabel yang tidak diteliti sebesar $23,9 \%$. Hal ini menujukkan bahwa terdapat faktor-faktor lain yang dapat mempengaruhi variabel kepuasan guru, seperti Kepemimpinan Kepala Sekolah, Budaya organisasi, fasilitas kerja, Pendidikan dan Pelatihan, dan lainlain.

\section{b. Saran (Suggestions)}

1) Dari hasil penelitian ini, menunjukkan cukup besar pengaruh motivasi kerja guru SMK Negeri seKabupaten Bireuen dalam mendorong guru sehingga puas bekerja. Oleh karenanya, perlu peran Kepala Sekolah yang lebih aktif dan perhatian dalam meningkatkan motivasi kerja guru.

2) Sedangkan Kompensasi sebagai faktor yang melekat pada diri guru berupa rangsangan kerja dengan adanya pendapatan yang cukup untuk kebutuhannya akan mendorong guru puas dalam bekerja dengan baik dan berusaha untuk kerja yang berprestasi. Oleh karenanya, hal ini menjadi perhatian besar dan serius dari pimpinan sekoah, pemerintah daerah dan pemerintah pusat.

3) Demikian pula, iklim organisasi sekolah tidak kalah menarik untuk selalu dijaga dan dipelihara. Karena hal ini terkait dengan factor yang mempengaruhi kepuasan guru.

\section{DAFTAR PUSTAKA (References)}

1) Davis dan Newstorm, 2000. Perilaku dalam Organisasi. Jakarta : Peneerbit Salemba Empat.

2) Dessler, G, 2007, Manajemen Personalia, Edisi Ketiga, Jakarta: Erlangga.

3) Edy Sutrisno, 2010. Manajemen Sumber Daya Manusia. Kencana. Jakarta

4) Eklund, N. 2008. How Was Your Day at School? Improving Dialogue about Teacher Job Satisfaction. USA: Search Institute

5) Halawa, Filizaro. 2002. Kepuasan Kerja Guru SMA di Jakarta Timur. Universitas Negeri Jakarta.

6) Hasibuan, M, S. P., 2008., Manajemen Sumber Daya Manusia, cetakan kesembilan, Jakarta : PT Bumi

7) Hasibuan, M, S.P. 2009. Manajemen Sumber Daya Manusia. Bumi Aksara. Jakarta.

8) Hasibuan, Malayu S.P, 2003, Manajemen Sumber Daya Manusia, Edisi Revisi,. Bumi Aksara, Jakarta.

9) Handoko, H, 2001. Manajemen Personalia dan Sumber Daya Manusia. Yogyakarta: BPFE-Yogyakarta

10) Hoy, Wayne K. \& Miskel, Cecil G. 2001. Education Administration : Theory research, and practice (6th ed.,international edition). Singapore: Mc Graw-Hill Co

11) Husein Umar. 2002. Metode Riset Bisnis. Jakarta: Gramedia Pustaka. 
12) Kreitner, Robert dan Angelo Kinicki 2001. Organizational Behavior. New York: McGraw-Hill Companies

13) Luthans, Fred. 2006. Organizational Behavior. The McGraw-Hill Companies, Inc.

14) Mangkunegara, A. A. P., 2009., Manajemen Sumber Daya Manusia Perusahaan, Bandung, PT. Remaja Rosdakarya.

15) Marwan Hamid, Ibrahim Sufi, Win Konadi, dan Yusrizal Akmal, 2019. Analisis Jalur Dan Aplikasi Spss Versi 25, Edisi Pertama Sefa Bumi Persada, Medan.

16) Masrukhin dan Waridin, 2006, Pengaruh Motivasi Kerja, Kepuasan Kerja,. Budaya Organisasi dan Kepemimpinan terhadap

17) Nirwana, S.K. 2014, Analisis Jalur (Path Analysis),Unit Pelayanan Statitika Jurusan Statistika, Bandung : FMIPA UNPAD.

18) Mutiara S. Panggabean. 2002. Manajemen Sumber Daya Manusia. Bogor: Ghalia Indonesia

19) Pidarta, 1997

20) Pinkus, Lyndsay M. 2009. Moving Beyond AYP: High School Performance Indicators. Alliance for Excellent Education. 1-20. [Online]. Tersedia: http://www.all4ed.org/files/ SPIMovingBeyondAYP.pdf

21) Pretorius, Stephanus dan Villiers, Elsabe de. 2009. Educators' Perceptions of School Climate and Health in Selected Primary Schools. South African Journal of Education. (29). 33-52. [Online]. Tersedia: http://www.sajournalofeducation.co.za/index.php/saje/article/view/230/ 141

22) Rivai, Veithzal. 2004, Manajemen Sumber Daya Manusia. Jakarta : Raja. Grafindo

23) Rivai Veithzal dan Ella Jauvani Sagala, 2011. Manajemen Sumber Daya Manusia untuk Peursahaan dari Teori ke Praktik. PT. Raja Grafindo. Jakarta.

24) Robbins. S. P., \&Judge. T. A., 2009., Perilaku Organisasi, Jakarta: Salemba Empat

25) Robbins, Stephen \& Judge, Timothy. A. 2012. Perilaku Organisasi (Organizational Behavior). Jakarta:Salemba

26) Saeed, Rashid, Rab Nawaz Lodhi, Hafiz, Muhammad Abdul Hayee, Merium Shakeel, Zahid Mahmood, Moeed Ahmad. 2013. The Effect of Extrinsic Motivational Instruments on Job Satisfaction: A Case of Pakistani Financial Services Companies. World Applied Sciences Journal. Vol. 26, No. 12. pp. 1657-1661.

27) Sergiovani. 2006. Kemampuan Profesional Guru dan Tenaga Kependidikan. Bandung: Alfabeta.

28) Sekaran, Uma. 2006. Metodologi Penelitian untuk Bisnis. Edisi 4. Buku 2. Salemba Empat. Jakarta

29) Sorenson, Richard D., Goldsmith, Lloyd M. 2008. The Principal's Guide to Managing School Personnel. Corwin Press. [Online]. http://books.google.co.id/books?id=tomNInqEARcC

30) Sugiyono. 2012. Metode Penelitian Pendidikan Pendekatan Kuantitatif. Kualitatif. dan R\&D. Alfabeta. Bandung.

31) Sugiyono 2013. Statistika Untuk Penelitian. Alfabeta. Bandung.

32) Tubbs, J. Eric., Garner, Mary. 2008. Impact Of School Climate On School Outcomes. Journal of College Teaching \& Learning. 5(9). 17-26. [Online]. Tersedia: http://www.cluteinstitute-onlinejournals.com/ PDFs/1212.pdf

33) Zain Ikhwani Jihadi Robirodia, 2016. Pengaruh Kompensasi dan Iklim Organisasi Sekolah terhadap Kepuasan Kerja Guru non PNS Madrasah Aliyah, Jurnal Administrasi Pendidikan Vol.XXIII No.1 April 2016, Program Studi Administrasi Pendidikan, Sekolah Pascasarjana Universitas Pendidikan Indonesia. 